\title{
Some cellular correlates of harpin-induced resistance to blue mold of apples
}

\author{
Guy de Capdeville ${ }^{1}$, Steven V. Beer ${ }^{2}$, Charles L. Wilson ${ }^{3}$ \& James R. Aist ${ }^{2}$ \\ ${ }^{1}$ Embrapa Recursos Genéticos e Biotecnologia, 70770-900, Brasília, DF, Brazil; ${ }^{2}$ Department of Plant Pathology, Cornell \\ University, Ithaca NY, 14853, USA; ${ }^{3}$ United States Department of Agricuture, ARS, Appalachian Fruit Research Station, \\ Kearneysville WV, 25430, USA
}

Corresponding author: Guy de Capdeville, e-mail: guy@cenargen.embrapa.br

\begin{abstract}
Harpin is a protein produced by Erwinia amylovora that is involved in its pathogenesis of apple. We studied cellular correlates of harpin-induced resistance in apple fruit to blue mold caused by Penicillium expansum using Light (LM), scanning (SEM) and transmission (TEM) electron microscopy. SEM study of wound surfaces showed the fungus colonizing the wounds within $48 \mathrm{~h}$, and profuse colonization of the wound and penetration of the tissue occurred within $72 \mathrm{~h}$ after inoculation of control samples. In harpin-treated samples, spore germination and wound colonization were not evident until $96 \mathrm{~h}$. LM showed that intramural mycelial growth appeared as early as $72 \mathrm{~h}$, and intense tissue colonization occurred by $96 \mathrm{~h}$ after inoculation in the control samples. In the harpin-treated fruit, spore germination and wound colonization occurred only by $144 \mathrm{~h}$ in the treated specimens. Numerous putative tannin vacuoles and appositions were observed in the epidermal and hypodermal cells of inoculated harpin-treated samples, but only a few appeared in control samples. TEM showed that intramural growth of the fungus occurred frequently in the controls. In harpin-treated specimens, wall depositions and appositions occurred very frequently. The results suggest that harpin may trigger or intensify cellular responses in harpin-treated apples.
\end{abstract}

Keywords: Penicillium expansum, Malus domestica, Red Delicious, alternative control.

\section{RESUMO}

Alterações celulares correlacionadas com a resistência induzida pela proteína Harpin em maçã contra o mofo azul

A proteína harpin está envolvida com a patogênese de Erwinia amylovora em maçã. Utilizou-se microscopia para estudar alterações celulares induzidas pela harpin que sejam correlacionadas com a resistência de maçã contra Penicillium expansum. Microscopia de varredura da superfície de ferimentos inoculados mostrou que o fungo iniciou colonização dos ferimentos $48 \mathrm{~h}$ após a inoculação e que profusa colonização dos tecidos ocorreu dentro de 72 h nos controles. Nos frutos tratados com harpin, germinação de esporos e colonização dos ferimentos foram evidentes em $96 \mathrm{~h}$. Somente após este tempo foi possível observar invasão dos tecidos pelas hifas que foram bloqueadas pela deposição de materiais amorfos no sítio de penetração. A microscopia de luz mostrou que nos controles crescimento micelial ocorreu dentro das paredes celulares em $72 \mathrm{~h}$ e que intensa colonização dos tecidos ocorreu em $96 \mathrm{~h}$. Nos frutos tratados a germinação de esporos e a colonização de ferimentos ocorreu 144 h após a inoculação. Numerosos vacúolos de tanino e deposições de material de parede foram observados nas células da epiderme e da hipoderme de amostras tratadas, mas poucos foram encontrados nas amostras dos frutos controle. Exames feitos com microscopia de transmissão mostraram que o crescimento do fungo dentro das paredes ocorreu freqüentemente nos controles, mas em frutos tratados as deposições na parede ocorreram muito freqüentemente e, em alguns casos, bloquearam o avanço do patógeno. Os resultados sugerem que esta proteína pode ativar ou intensificar respostas celulares de resistência em maçãs.

Palavras-chave: Penicillium expansum, Malus domestica, Red Delicious, controle alternativo.

\section{INTRODUCTION}

Blue mold, caused by Penicillium expansum Link, is the most important postharvest disease of apples and is responsible for most of the losses that occur during storage (Snowdon, 1990). Strategies to control blue mold have been based on avoiding damage during harvest and processing, on sanitation, on the use of controlled atmosphere storage and control of temperature and relative humidity, and on postharvest treatment of the fruit with fungicides, such as thiabendazoles, sometimes combined with wide-spectrum fungicides such as Captan (Prusky et al., 1985; Snowdon, 1990). Because of increasing problems related to fungicide toxicity, development of resistance by pathogens, and potential harmful effects of these chemicals on the environment and human health, as well as the necessity of reducing losses while reducing their use, new strategies for control have been proposed (Wilson et al., 1994). Alternative control measures using natural compounds such as harpin have been evaluated as promising alternatives in controlling post-harvest diseases, by inducing resistance in fruit (Capdeville et al., 2002; Yanga et al., 2005).

Harpin is an acidic, heat-stable, glycine-rich, $44 \mathrm{kDa}$ protein, encoded by the $h r p N$ gene of the bacterium Erwinia amylovora, and is the first known bacterial product able to 
elicit the hypersensitive response (HR) in plants (Baker et al., 1993; Dong et al., 1999; Mullin et al., 1998). It is also known to elicit systemic acquired resistance in tobacco and Arabidopsis (Dong et al., 1999) and to induce resistance in harvested Red Delicious apples (Capdeville et al., 2002; 2003). In the latter two citations the authors were able to show conclusively that harpin is able to reduce the damage caused by P. expansum when applied either after harvest or, preferably, before harvest. The best results were achieved when fruit were treated before harvest with concentrations of $20 \mu \mathrm{g} / \mathrm{mL}$ or above. When applied after harvest, fruit of different post-harvest ages responded quite differently in terms of resistance, where fresh fruit resisted blue mold infection better than did controlled atmosphere-stored fruit. These authors suggested that the effect of harpin on blue mold was most probably due to induced resistance, and that the resistance was time and concentration dependent.

It has been shown that harpin triggers a variety of cellular responses such as activation of active oxygen species and cell membrane depolarization, which are known to be involved in resistance response mechanisms of systemic resistance (Delaney, 1997; Dong et al., 1999). Harpin has been produced commercially under two trademarks, "Messenger ${ }^{\mathrm{TM}}$ " and Extend ${ }^{\circledR}$, and it is currently being commercialized and marketed for control of viral and fungal diseases as well as a plant growth enhancer and a controller of selected insect and microbial populations (Wei et al., 1998; Zitter \& Beer, 1998; Fonseca et al., 2005). While a considerable number of reports can be found in the literature about the molecular aspects of harpin-induced HR and SAR (Systemic Acquired Resistance) in many plants, there are no reports of work done with the objective of revealing possible cellular mechanisms that might be involved in harpininduced resistance in harvested apple fruit. When combined with existing knowledge of the molecular mechanisms involved in harpin-induced resistance, studies with this objective could help to elucidate the complex mode of action of harpin. Therefore, the main goal of the studies presented here was to explore possible structural changes induced by harpin treatment of Red Delicious apples inoculated with $P$. expansum, using light and electron microscopy to reveal structural correlates with resistance.

\section{MATERIAL AND METHODS}

To explore cellular correlates of resistance induced by treatment with harpin, ripe apples (cv. Red Delicious) were harvested at the Cornell University Orchard, Ithaca, $\mathrm{NY}$, brought to a controlled environment chamber at $22^{\circ} \mathrm{C}$, washed thoroughly with distilled water, and allowed to dry while acclimatizing for $4 \mathrm{~h}$. The fruit were then sprayed with water (control) or an aqueous solution of Messenger ${ }^{\circledR}$, the commercial formulation of harpin, at a harpin concentration of $80 \mathrm{mg} / \mathrm{L}$. Ninety-six hours after treatment, a wound 2 $\mathrm{mm}$ deep and $2 \mathrm{~mm}$ in diameter was made in each fruit. Each wound was then flooded with a $20 \mu \mathrm{L}$ drop of a spore suspension of $P$. expansum at $5 \times 10^{3}$ spores $/ \mathrm{mL}$ (ca. 100 spores per wound). Control fruit were those treated with harpin, wounded, but not inoculated with the pathogen, and untreated and non-inoculated fruit.

\section{Inoculum preparation}

An isolate (USCU1) of Penicillium expansum kept in the USDA Agricultural Fruit Research Station collection (Kearneysville, WV) was used as the source of inoculum for the experiments. The pathogenicity of the isolate was checked by inoculating Red Delicious apple fruit (Malus domestica Borkh.). Pieces of tissue were removed from the edge of the lesions formed in those inoculated fruit, immersed in $70 \%$ ethanol for $1 \mathrm{~min}$, transferred to a solution of $1 \%$ sodium hypochlorite for 1 minute, washed 3 times for 2 minutes each in sterile distilled water, blotted on sterile filter paper, and plated on PDA medium amended with $0.1 \%$ streptomycin. The plates were placed in a growth chamber at $24^{\circ} \mathrm{C}$ and, after colonies were formed, disks of mycelium were removed from the edge of the colony and transferred to assay tubes containing PDA plus $0.1 \%$ streptomycin, allowed to grow for 3 days at $24^{\circ} \mathrm{C}$, and then stored in the refrigerator at $5^{\circ} \mathrm{C}$. These stock cultures were tested for pathogenicity every four months. The stocks were used for generating new, 10-day-old colonies on PDA plus $0.1 \%$ streptomycin from which spores were collected in sterile water amended with $0.01 \%$ Tween 20 . The final concentration of the spore suspension to be used was adjusted using a hemacytometer.

\section{Scanning electron microscopy studies}

For scanning electron microscopy, whole wounds were dissected out using a single edge razor blade (Electron Microscopy Sciences, Ft. Washington, PA) from six inoculated fruit per treatment 3, 6, 12, 24, 48, 72 and 96 $\mathrm{h}$ after inoculation. The wounds were immersed in $2.5 \%$ glutaraldehyde in $0.1 \mathrm{M}$ sodium cacodylate buffer at $\mathrm{pH} 6.8$ for $30 \mathrm{~min}$ at room temperature, during which each wound was cut into two halves. The samples were then transferred to a fresh solution of the same fixative for $30 \mathrm{~min}$ more at room temperature and then for an additional $90 \mathrm{~min}$ at $4^{\circ} \mathrm{C}$. Samples were rinsed with the same buffer and post-fixed for $2 \mathrm{~h}$ at room temperature in $2 \%(\mathrm{v} / \mathrm{v})$ osmium tetroxide in $0.1 \mathrm{M}$ sodium cacodylate buffer, $\mathrm{pH}$ 6.8. The samples were then dehydrated in a graded ethanol series and dried using a BAL-TEC 030 CPD Critical Point Dryer (BAL-TEC AG, Balzers, Zürich). Dried samples were mounted on aluminum stubs and coated with gold-palladium using a BAL-TEC 050 sputter coater (BAL-TEC AG, Balzers, Zürich). The samples were examined using a Zeiss DSM 960 scanning electron microscope (LEO Electron Microscopy Ltd, Cambridge, $\mathrm{UK})$ at $4 \mathrm{kV}$.

\section{Transmission electron microscopy studies}

For transmission electron microscopy, nine $1 \mathrm{~mm}-$ thick tissue samples were collected from the wound area including the parenchymal tissues that compose the wound 
surface, and also from about $3 \mathrm{~mm}$ of unwounded tissue at the edges of the wound (including epidermal cells), where in some cases the fungus tried to penetrate. The samples were collected $12,36,72,96$ or $144 \mathrm{~h}$ after inoculation, and immediately immersed in $2.5 \%$ glutaraldehyde in 0.1 $\mathrm{M}$ sodium cacodylate buffer at $\mathrm{pH} 6.8$ for $30 \mathrm{~min}$ at room temperature. The samples were then transferred to fresh preparations of the same fixative and held for $30 \mathrm{~min}$ more at room temperature, and then for an additional $90 \mathrm{~min}$ at $4^{\circ} \mathrm{C}$. Samples were rinsed with the same buffer and postfixed for $1 \mathrm{~h}$ at room temperature in $2 \%(\mathrm{v} / \mathrm{v})$ osmium tetroxide in $0.1 \mathrm{M}$ sodium cacodylate, $\mathrm{pH}$ 6.8. The samples were washed in the same buffer, dehydrated in a graded ethanol series, and then embedded in Spurr's epoxy resin (Electron Microscopy Sciences, Ft. Washington, PA). Ultra-thin sections were cut with a diamond knife (Micro Star, Huntsville, TX) using a Reichert OM2 ultramicrotome (Leica Microscopy Systems, Heerbrugg, Switzerland), collected on formvar-coated copper grids (300 $\mathrm{x}$ 75 mesh) and stained with uranyl acetate and lead citrate. The sections were examined with a Philips EM 201 transmission electron microscope (FEI, Hillsboro, OR) at $80 \mathrm{kV}$.

Light microscopy studies. For light microscopy, sample blocks of the same treatments prepared for the TEM work were sectioned with glass knives. One micrometer cross and longitudinal sections were mounted on glass slides, stained with $1 \%$ toluidine blue-O or azure B for 2 minutes on a hot plate, and rinsed with deionized water. Sections were dried and then mounted in immersion oil and examined using a Zeiss Universal light microscope (LEO Electron Microscopy Ltd, Cambridge, UK), equipped with a Canon A-1 camera (Canon U.S.A. Inc., Lake Success, NY), using bright field, phase contrast or Nomarski differential interference contrast optics. About thirty sections per treatment were examined, and from each treatment three sections were randomly selected and examined for the presence of putative condensed tannin vacuoles. To check if the idioblasts actually contained vacuolated tannin, we stained some fresh sections with ferrous sulphate to look for brownish-orange stained phenolic compounds (Bussoti et al., 1998). The data obtained were analyzed statistically using analysis of variance procedures.

\section{RESULTS}

\section{Wound surface colonization by Penicillium expansum}

SEM analysis of inoculated wounds of fruits not treated with harpin showed that $P$. expansum began to colonize the wounds and penetrate the fruit by $48 \mathrm{~h}$ after inoculation, and no apparent cellular responses were seen at penetration sites (Figures 1A-B). Profuse mycelial growth and colonization occurred by $72 \mathrm{~h}$, as intramural and intracellular growth occurred without any visible structural reaction by the apple cells (Figures 1C-D). By 96 h, a considerable number of spore-bearing structures could be seen in many areas of the wounds, and the newly formed conidiophores contributed more spores to the wounds (Figures 1E-F).
In wounds of harpin-treated fruit, spore germination and wound colonization were not found until $96 \mathrm{~h}$ after inoculation. In these wounds a flocculent material commonly covered spores of $P$. expansum and starch grains found frequently in the wounds (Figure 2A). The flocculent material occurred as early as $12 \mathrm{~h}$ after inoculation (Figure 2B) and became more apparent and widely spread on the wound surface as time between treatment and inoculation increased (Figures 2C-D). Spore germination and mycelial growth could be seen only in areas of the samples where minimal amounts or no flocculent material could be found (Figure 2E). A penetration attempt $96 \mathrm{~h}$ after inoculation may have been halted by some kind of deposition at the penetration point, where damage to the hypha can be seen (Figure 2F). No alterations were observed on cells in the wounds of control fruit.

\section{Tissue colonization by Penicillium expansum}

Light microscopy examination of thick sections from the wound area of the harpin-treated samples showed that intramural or intracellular growth was not as frequent as in the controls. However, in the control apples, the fungus grew in the inter- and intra-cellular spaces of fruit inoculated 72, 96 and $144 \mathrm{~h}$ after treatment (Figures 3A-C). Large numbers of putative condensed tannin vacuoles occurred in the cells (idioblasts) of the epidermis and the hypodermis of all harpin-treated samples (Figure 3E). In the controls (inoculated or not), putative tannin vacuoles also occurred, albeit in significantly smaller numbers than in the harpintreated fruit, but no differences between sampling times were observed (Table 1). The composition of these vacuoles could not be precisely determined without a more detailed biochemical analysis, but staining fresh sections with ferrous sulphate did result in the staining of these vacuoles with a brownish-orange colour characteristic of stained tannins (data not shown). Since the presence of tannin in apple tissue has been shown already (Lees et al., 1995), we inferred that these vacuoles were indeed full of tannin.

Large wall appositions were seen frequently in the harpin-treated samples, and in some instances these appositions may have trapped the fungus, which appeared as a blackened area in the center of the apposition (Figures 3D and F). Overall, harpin-treated samples removed from the area surrounding the inoculated wound displayed better cell integrity in the epidermis and hypodermis (Figure 3D) than did the controls (Figure 3A).

TEM examination of ultrathin sections of harpintreated samples showed the occurrence of multiple wall depositions or appositions in the host cells. Such structures occurred in either the intercellular spaces (Figures 4A and D) or inside the cells (Figures $4 \mathrm{~B}$ and C). These wall structures appear to have originated independently of the presence of the fungus, since they could be found in large numbers in many areas where the fungus was not present (Figures 4B and D). However, in some instances fungal hyphae growing in the intercellular spaces were encased in large depositions 

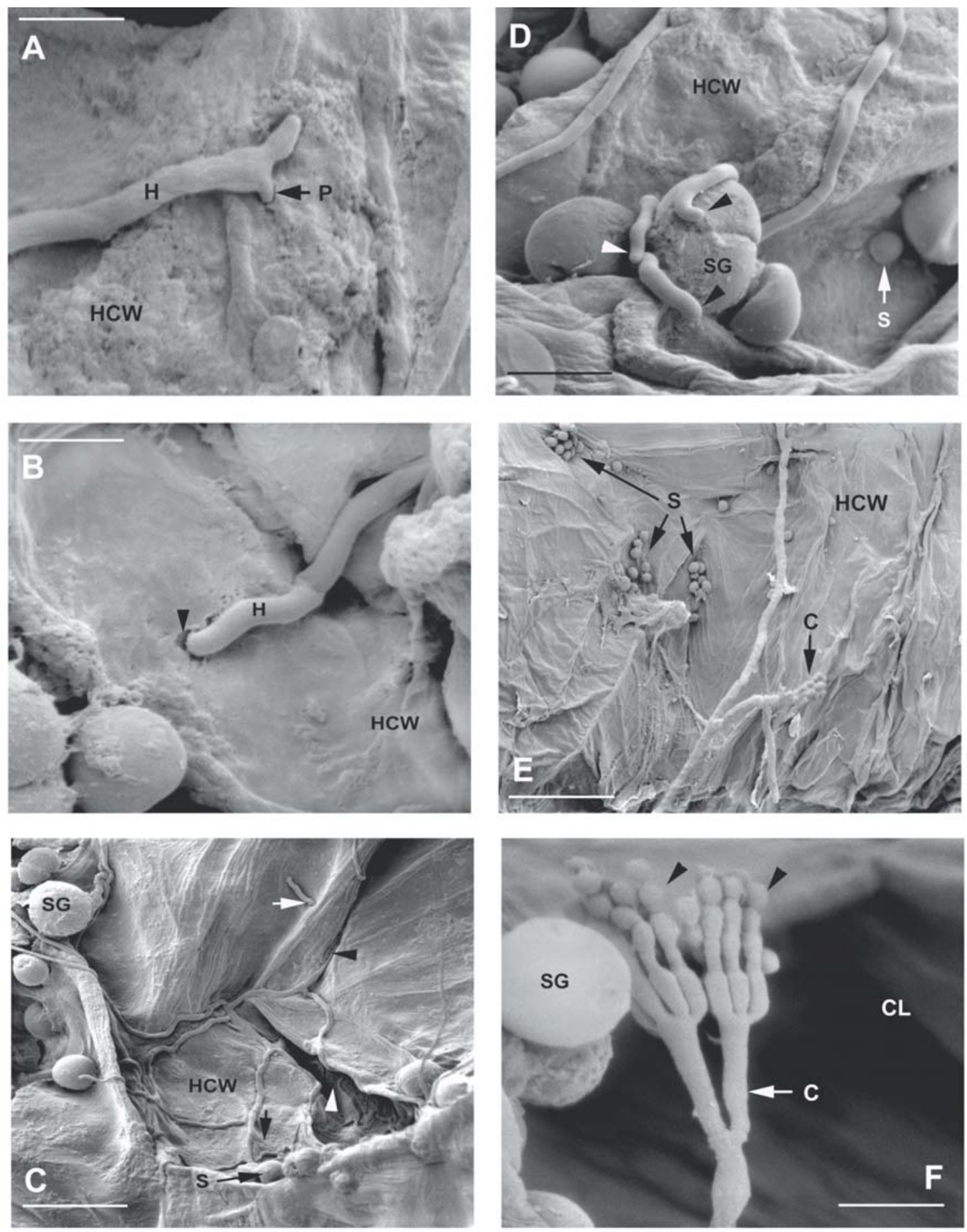

FIG. 1 - Scanning electron micrographs of wound samples of control apple fruit treated with water and inoculated with P. expansum 96 hours after treatment. A. Hyphae of the fungus $(\mathrm{H})$ began to colonize the wound and penetrated $(\mathrm{P})$ the tissue as early as 48 hours following inoculation. Scale bar $=5 \mu \mathrm{m}$; B. Penetration of the host cell wall $(\mathrm{HCW})$ by the fungus hypha $(\mathrm{H})$ seemed to rely on enzymatic digestion (arrowhead), as there is degradation of the cell wall around the penetrating hyphae. Scale bar $=4 \mu \mathrm{m}$; C. Profuse fungal growth occurred on the surface of the wound by 72 hours after inoculation, and penetration of the host cell walls (HCW) occurred into (arrows) and between (arrowheads) the cells without any visible host resistance barriers formed at the penetration point. Note the presence of starch grains (SG) and spores of P. expansum (S). Scale bar $=20 \mu \mathrm{m}$; D. Multiple hyphal tips (arrowheads) could be seen growing on starch grains (SG) and on the host cell wall $(\mathrm{HCW}) . \mathrm{S}=$ spore. Scale bar $=10 \mu \mathrm{m}$; E. Sporulation of the fungus could be found in the wounds by 96 hours after inoculation, when conidiophores (C) released many new spores (S) onto the host cell wall $(\mathrm{HCW})$. Scale bar $=20 \mu \mathrm{m} ; \mathbf{F}$. Numerous conidiophores $(\mathrm{C})$ were found in many areas of the wound surface or arising from the lumen $(\mathrm{CL})$ of a damaged cell. $\mathrm{SG}=$ starch grain. Scale bar=6.5 $\mu \mathrm{m}$. 

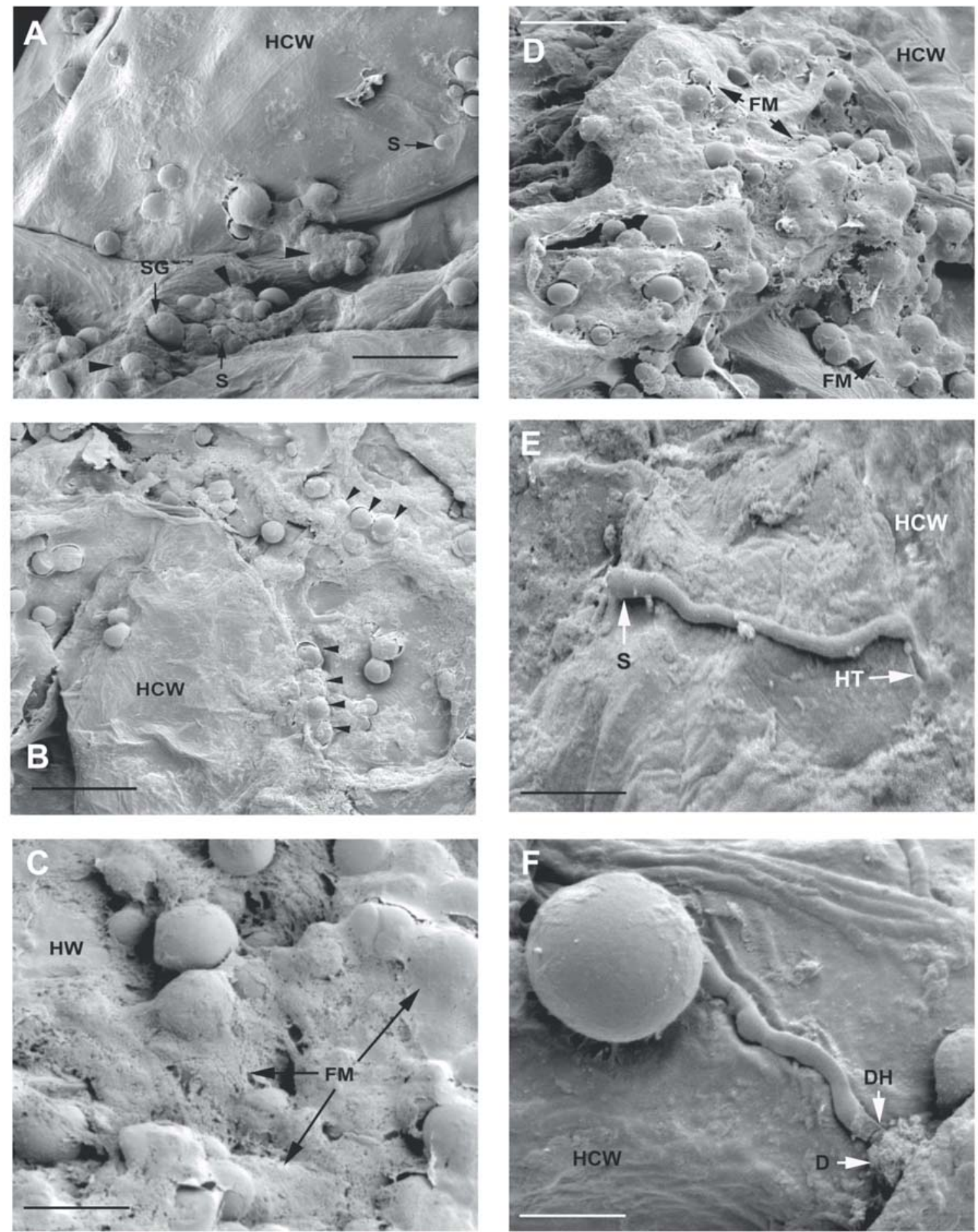

FIG. 2 - Scanning electron micrographs of wound surfaces of harpin-treated apple fruit inoculated with Penicillium expansum 96 hours after treatment. A. Spores of $P$. expansum (S) and starch grains (SG) can be seen covered by some kind of flocculent material (arrowheads) 12 hours after inoculation. Scale bar $=20 \mu \mathrm{m} ;$ B. Chains of conidia covered by flocculent material (arrowheads) 24 hours after inoculation. $\mathrm{HCW}=$ host cell wall. Scale bar $=20 \mu \mathrm{m}$; C. Flocculent material (FM) covering spores of $P$. expansum and starch grains 48 hours after inoculation. Scale bar $=20 \mu \mathrm{m} ; \mathbf{D}$. Abundant flocculent material $(\mathrm{FM})$ on the surface of the wound 72 hours after inoculation. Scale bar $=20$ $\mu \mathrm{m} . \mathrm{HCW}=$ host cell wall; E. A spore of $P$. expansum (S) germinating in an area free of flocculent material 96 hours after inoculation. HT $=$ hyphal tip. Scale bar $=20 \mu \mathrm{m} ; \mathbf{F}$. Penetration attempt apparently halted by some kind of material deposited at the penetration point (D) 96 hours after inoculation. Note the damaged hyphae (DH). HCW $=$ host cell wall. Scale bar $=20 \mu \mathrm{m}$. 

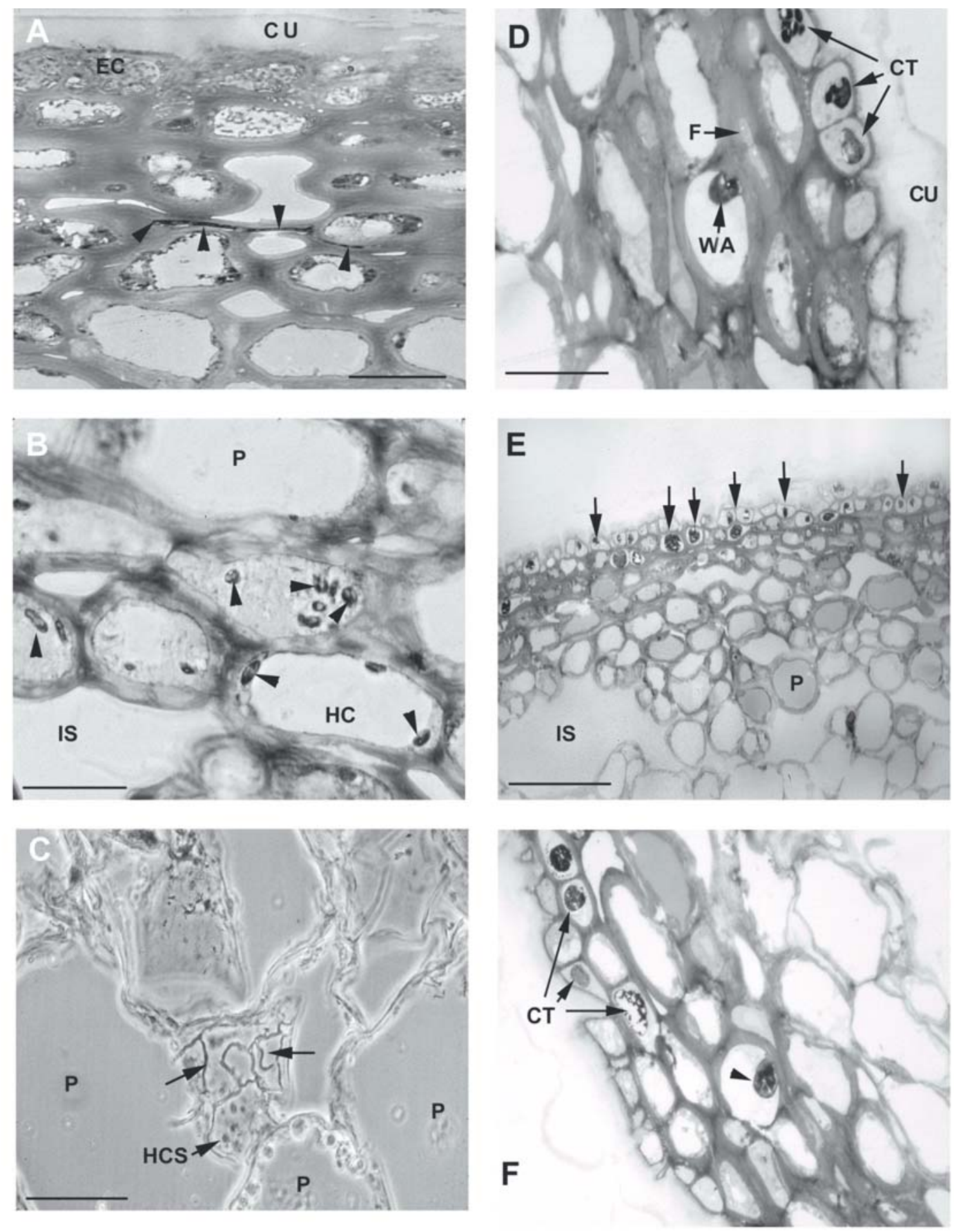

FIG. 3 - Light micrographs of control (A, B, C) and harpin-treated (D, E, F) apple fruit samples (from tissue collected at the wound surface as well as at the edge of the wound) inoculated with Penicillium expansum 96 hours after treatment. A. Intramural growth of $P$. expansum could be seen 72 hours after inoculation (arrowheads). Note that epidermal (EC) and hypodermal cell integrity appears compromised. CU $=$ cuticle. Scale bar $=20 \mu \mathrm{m}$; B. Cross sections of hyphae (arrowheads) colonizing parenchyma $(\mathrm{P})$ cells 96 hours after inoculation. IS $=$ intercellular space, $\mathrm{HC}=$ host cell. Scale bar $=10 \mu \mathrm{m} ; \mathbf{C}$. Intense colonization (arrows) of parenchyma cells at the wound surface 144 hours after inoculation. HCS = hyphae cross sections. Scale bar $=20 \mu \mathrm{m}$; D. Intramural growth of $P$. expansum (F) occurring in hypodermis cells at the edge of the wound 144 hours after inoculation. Note the large wall apposition (WA) close to the area where the fungus hypha is present. $\mathrm{CT}=$ putative condensed tannin, $\mathrm{CU}=$ cuticle. Scale bar $=13 \mu \mathrm{m}$; E. A large number of putative condensed tannin vacuoles (arrows) in cells (idioblasts) of the epidermis and hypodermis at the edge of the wound 36 hours after inoculation. $\mathrm{P}=$ parenchyma, IS $=$ intercellular spaces. Scale bar $=40 \mu \mathrm{m} ; \mathbf{F}$. Large wall Apposition (arrowhead) trapping the fungus inside a parenchyma cell (at the edge of the wound) 144 hours following inoculation. $\mathrm{CT}=$ condensed tannin vacuoles. Scale bar $=23 \mu \mathrm{m}$. 
Some cellular correlates of harpin-induced resistance...

TABLE 1 - Percentage of putative condensed tannin cells (idioblasts) in the first two layers of cells of harpin-treated and non-harpin-treated fruit peel samples

\begin{tabular}{lccccccc}
\hline \hline $\begin{array}{l}\text { Sampling } \\
\text { time }\end{array}$ & $\begin{array}{c}\text { Treatment }^{\mathbf{b}} \\
\text { Section }^{\mathbf{c}}\end{array}$ & \multicolumn{2}{c}{ No. cells/ section } & \multicolumn{2}{c}{ No. idioblasts } & \multicolumn{2}{c}{ Idioblasts (\%) } \\
Ctrl & Harp & Ctrl & Harp & Ctrl & Harp \\
\hline \multirow{3}{*}{12} & 1 & 63 & 80 & 2 & 11 & 3.2 & 13.7 \\
& 2 & 55 & 51 & 1 & 8 & 1.8 & 15.7 \\
& 3 & 69 & 46 & 0 & 4 & 0 & 8.7 \\
36 & 1 & 62 & 66 & 3 & 12 & 4.8 & 18.1 \\
& 2 & 65 & 72 & 0 & 14 & 0 & 19.5 \\
& 3 & 59 & 67 & 6 & 36 & 10.2 & 53.7 \\
72 & 1 & 66 & 78 & 5 & 9 & 7.6 & 11.5 \\
& 2 & 72 & 62 & 2 & 19 & 2.7 & 30.6 \\
& 3 & 59 & 72 & 0 & 32 & 0 & 44.5 \\
96 & 1 & 61 & 73 & 4 & 27 & 6.5 & 37.1 \\
& 2 & 66 & 69 & 1 & 21 & 1.5 & 30.4 \\
& 3 & 72 & 71 & 8 & 28 & 11.2 & 39.4 \\
144 & 1 & 62 & 78 & 2 & 10 & 3.2 & 12.8 \\
& 2 & 59 & 72 & 0 & 25 & 0 & 34.7 \\
& 3 & 71 & 68 & 5 & 20 & 5.6 & 29.4 \\
\hline
\end{tabular}

${ }^{a}$ Sample sections were collected from all sampling times used for the light microscopy and TEM work.

${ }^{\mathrm{b}}$ Samples were collected from non-harpin treated (Ctrl) and from harpin-treated (Harp) fruit.

${ }^{c}$ One-micrometer thick sections were randomly selected from the total sample used in the light microscopy work, and the number of idioblasts was calculated using a light microscope at the magnification of $160 \mathrm{X}$

${ }^{d}$ The percentages of idioblasts were determined by calculating the number of cells containing condensed tannin vacuoles in the epidermis and in the first layer of cells of the hypodermis. Significant differences between the control and harpin-treated samples were detected $(P=0.0001)$, but no significant differences existed between the sampling times $(P=0.1865)$.

(Figure 4A). In fruit not treated with harpin, hyphae of the fungus were frequently seen growing through the cell walls of the host cells (Figures 5A-B). Cross-sections as well as longitudinal sections of hyphae of the fungus could be seen in many areas of the examined samples, especially in the samples of control fruit inoculated 96 and $144 \mathrm{~h}$ after treatment with water (Figures 5A-D). No host cell responses were found that might have conceivably resisted the advance of the fungus in control samples. Few wall appositions were seen in harpin treated but not inoculated fruit, and no wall alterations were observed in tissue of untreated and not inoculated fruit. We did not have any TEM samples showing the flocculent material, because in both the light microscopy and the TEM work we decided to focus on changes below the wound surface.

\section{DISCUSSION}

In this study, we have tried to reveal some of the possible mechanisms involved in the ability of harpin to induce resistance in apple fruit to blue mold caused by $P$. expansum by looking for structural correlates of resistance. Using microscopy techniques, we showed that harpin treatment either prevented or delayed the colonization of the fruit by the pathogen. In harpin-treated fruit, colonization of the wound by the fungus did not occur until $96 \mathrm{~h}$ following inoculation, whereas in the control fruit, colonization was detected within $48 \mathrm{~h}$ following inoculation.

During examination of wound from harpin-treated fruits, a flocculent material was frequently seen partially or totally covering the spores of $P$. expansum. In these wounds colonization was limited to areas where the flocculent material was not present. In wounds of control fruits the flocculent material was not seen. To the extent of our knowledge, no such flocculent material has been reported in another plant-pathogen as a resistance response. Based solely on the work we have done, it would be difficult to explain what effect this flocculent material may have had on the fungus, but its constant presence in the treated fruit may have, in some way, inhibited the ability of the fungus to germinate and colonize the wound. One could speculate that this flocculent material could be some type of defensin produced by the fruit cells.

One of the most interesting findings of this work was the occurrence of a large number of putative tannin idioblasts in the harpin-treated samples. The presence of a large number of putative tannin vacuoles in both the epidermis and the hypodermis of harpin-treated fruit as early as $12 \mathrm{~h}$ after treatment was indicative of intense cellular metabolic activity. Tannins are a specific category of 

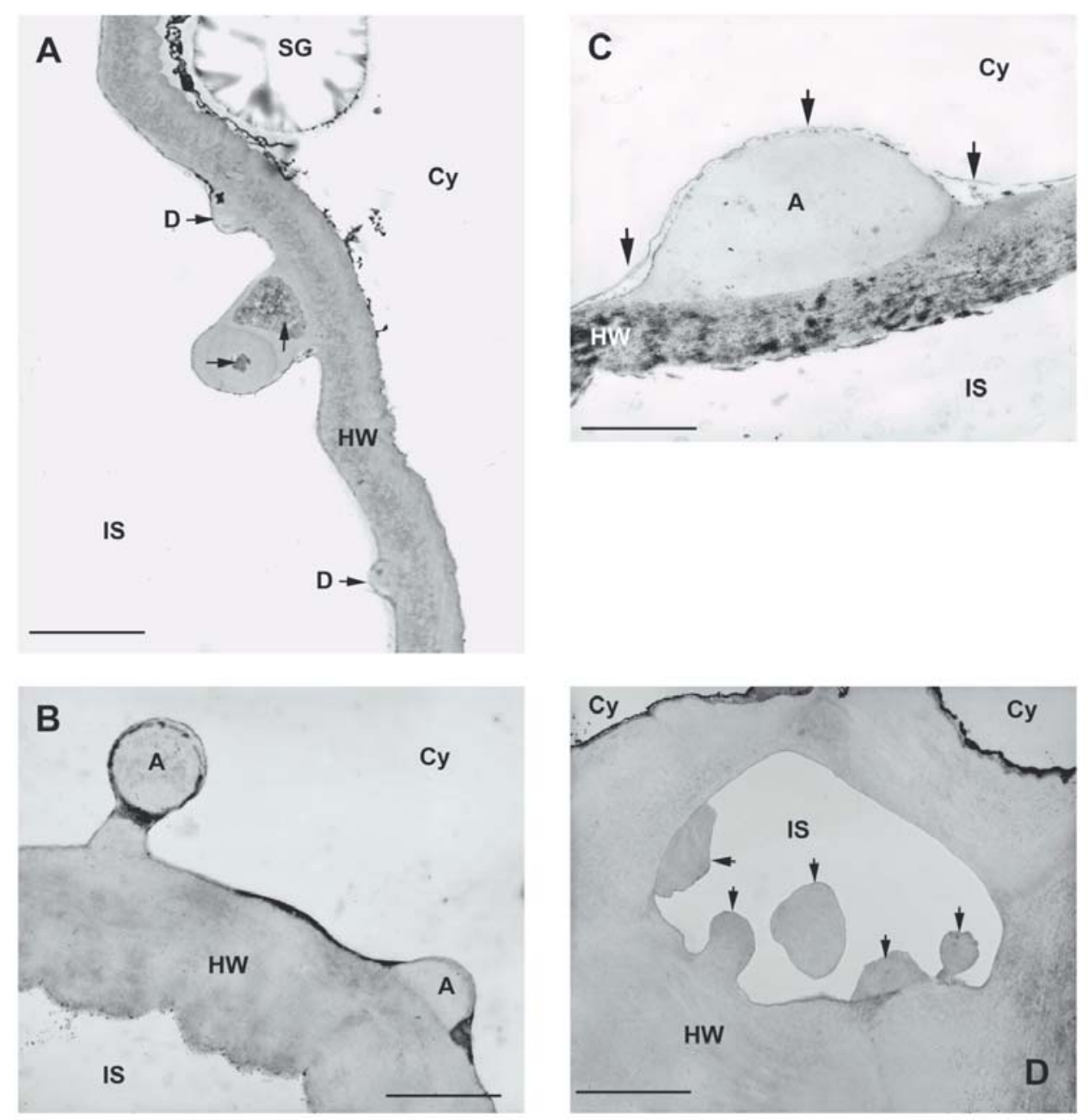

FIG. 4 - Transmission electron micrographs of harpin-treated apple fruit samples inoculated with $P$. expansum 96 hours after treatment. A. Occurrence of multiple wall depositions (D) in the intercellular spaces (IS) 144 hours after inoculation. Note the larger deposition seemingly trapping the fungus at two different points (arrows). $\mathrm{SG}=$ starch grain, $\mathrm{Cy}=$ cytoplasm, $\mathrm{HW}=$ host cell wall. Scale bar $=5 \mu \mathrm{m}$; B. Multiple wall appositions (A) occurred inside the cells independently of the presence of the fungus. $\mathrm{Cy}=$ cytoplasm, $\mathrm{HW}=$ host cell wall, $\mathrm{IS}=$ intercellular space. Scale bar = $2.5 \mu \mathrm{m} ; \mathbf{C}$. Intracellular wall appositions (A) of different shapes occur very frequently in the treated samples. Note the presence of the tonoplast (arrows) closely associated with the apposition 144 hours after inoculation. IS = intercellular space, $\mathrm{Cy}=$ cytoplasm, $\mathrm{HW}=$ host cell wall. Scale $\mathrm{bar}=2$ $\mu \mathrm{m}$; D. Multiple wall depositions (arrows) occurring in the intercellular spaces (IS) independently of the presence of the fungus. $\mathrm{Cy}=$ cytoplasm, $\mathrm{HW}=$ host cell wall. Scale bar $=6.7 \mu \mathrm{m}$.

phenolic compounds of high molecular weight, which have antioxidant properties, and may function as reserve materials for carbohydrate metabolism, according to Esau (1965). Furthermore, Ledbetter and Porter (1970) pointed out that tannin might also accumulate in plant tissue in response to attack by pathogens. Induction of accumulation of tannin in response to pathogen attack, wounding, and other factors affecting plants has been reported previously (Spiers et al., 1998). These last authors have studied the seasonal resistance to colonization of xylem cells in Golden Delicious apple fruit by Chondrostereum purpureum, and found that infection attempts by the fungus were frequently halted by immersion of hyphae in tannin-like deposits that occurred in the xylem vessels. In the present work, we were not able to show 

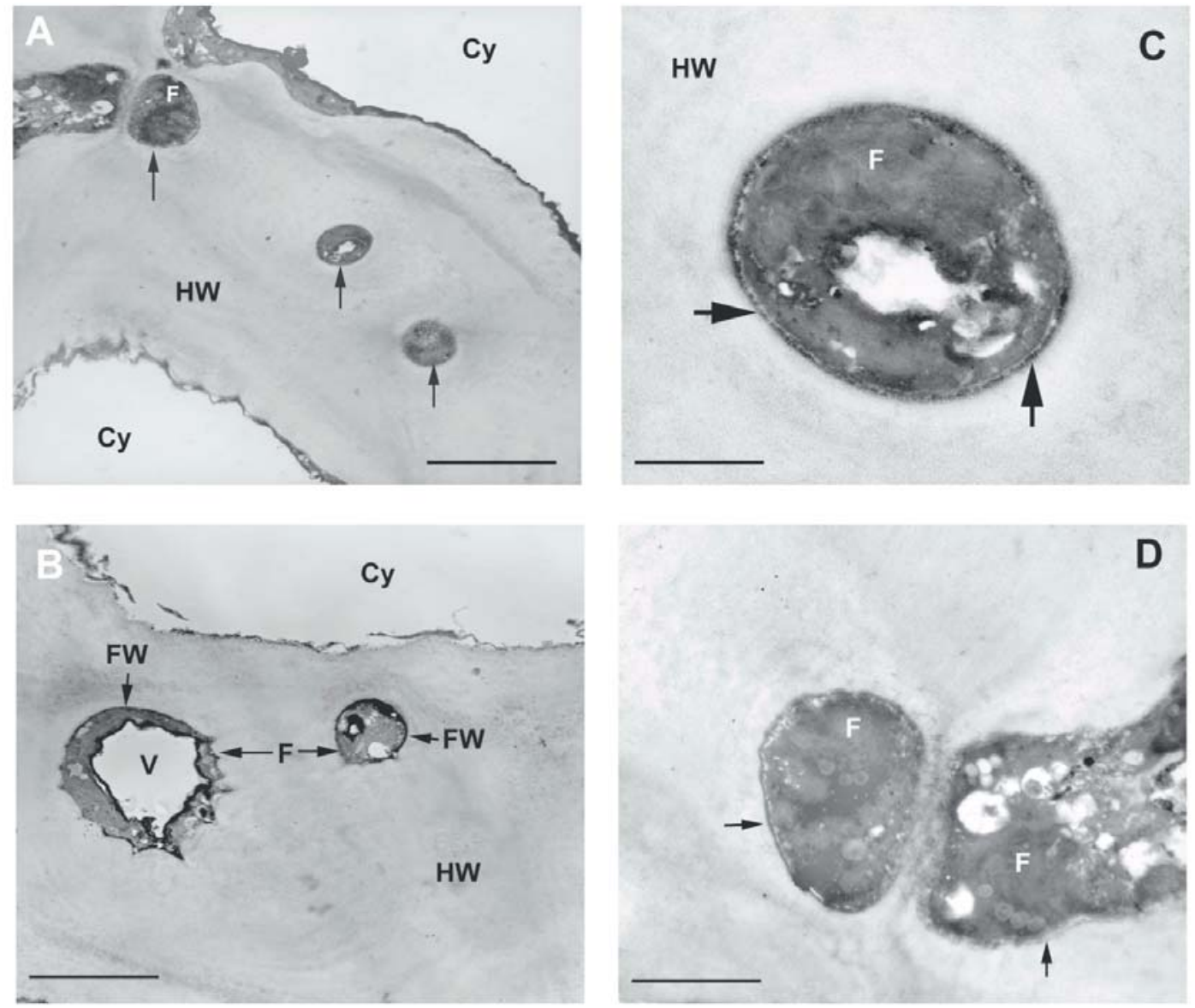

FIG. 5 - Transmission electron micrographs of non harpin-treated apple fruit samples inoculated with $P$. expansum 96 hours after treatment. A. Longitudinal and cross sections of fungal hyphae growing intramurally (arrows) 96 hours after inoculation. $\mathrm{F}=$ fungus, $\mathrm{Cy}=$ cytoplasm, $\mathrm{HW}=$ host cell wall. Scale bar $=4 \mu \mathrm{m}$; $\mathbf{B}$. Cross sections of hyphae of the fungus (F) growing through the host wall (HW) 144 hours after inoculation. $\mathrm{Cy}=$ cytoplasm, $\mathrm{FW}=$ fungus cell wall, $\mathrm{V}=$ fungus vacuole. Scale bar $=2.3 \mu \mathrm{m}$; C. Cross section of a fungal hypha (F) growing in the host wall (HW) 96 hours after inoculation. Note the fungus cell wall (arrows). Scale bar $=1.1 \mu \mathrm{m}$; D. Longitudinal section of a hypha of the fungus (F) growing through the host wall 96 hours after inoculation. The arrows show the fungus cell wall. Scale bar $=2.3 \mu \mathrm{m}$.

conclusively that tannin had a direct effect on P. expansum, but it is possible that tannin or its phenolic precursors could inhibit the ability of the fungus to invade tissue containing large amounts of such compounds. Condensed tannin has been found in hypodermis, parenchyma, and xylem cells of apple fruit (Lees et al., 1995; Spiers et al., 1998). The occurrence of putative condensed tannin vacuoles in the epidermis of harpin-treated fruit is a good indication of intense metabolic activity there and indicates that harpintriggered reactions in the epidermal cells could give these cells the ability to resist a potential pathogen attack. It is important to mention that harpin-treated fruits did not show any change in color or taste, despite the presence of putative condensed tannin vacuoles.

In wounds of control fruit it was very common to find hyphae penetrating the tissue directly through the cell wall as well as through the intercellular spaces. However, in the harpin-treated fruit, penetration of the tissue was not frequent and, in some instances, penetration attempts were halted by depositions around the penetration point. These effects on harpin-treated samples may explain, at least partially, the infrequent and sparse tissue colonization of the treated fruits. Wall-like depositions were frequently seen occurring in large numbers throughout the samples. In some cases, these depositions seemed to occur in response to penetration by the fungus, but they also occurred independently of the presence of the fungus in the vicinity of the site of deposition. Wall depositions occurred also in the controls, but to a much lesser extent and frequency. Indeed, colonization of non-treated samples occurred frequently 
between cell walls without any visual resistance by the invaded cell wall. This fact suggested that harpin was able to induce alterations in cell walls independently of the presence of the fungus. Induction of cell wall alterations in response to treatments with alternative control and biocontrol agents has been reported previously (Aist et al., 1988; Benhamou, 1995; El Ghaouth, 1994; Rioux \& Biggs, 1994). In those studies, wall alterations such as papillae formation, wall-like material depositions, wall thickening, and hemispherical protuberances commonly were seen in the host, associated or not with the presence of the pathogen.

We believe that at least some of the responses found in the present study may be part of a much larger complex of responses that may occur in fruit, which lead to resistance to disease. In previous studies we showed that harpin induces resistance in apple fruits against blue mold, and that the level of induced resistance depends on the harpin concentration and the interval between treatment and inoculation (Capdeville et al., 2002). Harpin has been shown to induce a hypersensitive response and systemic acquired resistance in tobacco, Arabidopsis and other plants (Dong et al., 1999; Peng et al., 2003; Terry and Joyce, 2004). Dong et al. (1999) demonstrated that harpin induces the expression of pathogenesis-related (PR) genes and other early response activators including active oxygen species. Their studies also indicated that resistance is systemic and that resistance response mediators are activated in as little as a few minutes following treatment with harpin.

It is important to emphasize that our main objective was not to study the effect of harpin on apple, but rather to find out what structural host responses occurred when harpininduced resistance was being expressed. Because of this, we have examined the infection process only in harpin-treated versus water-treated apples. The important point in the present work is that with treated and inoculated apples we were able to find differences relative to the untreated and inoculated apples.

The results of this study support the notion that besides other effects that harpin may have on apple fruit, induced resistance is one of the most important effects and may culminate in disease control. This initial, ground-breaking study is the first of its kind dealing with harpin-induced resistance in apple, and the search should continue to explore other possible mechanisms such as expression of PR genes and accumulation of phytoalexins, to better understand the molecular and cytological bases of harpininduced resistance to pathogens in harvested apple fruit. It is important to consider that apple is a compatible host for Erwinia amylovora, the bacterium that produces harpin. The fact that harpin can trigger relatively rapid responses that may affect the infection process by $P$. expansum in apple is, indeed, an intriguing and interesting point that could be studied further, especially at the molecular level.

\section{ACKNOWLEDGMENTS}

This research was supported mostly by the Cornell Agricultural Experiment Station Federal Formula Funds,
Project No. NYC-153410, received from Cooperative State Research, Education and Extension Service, U.S. Department of Agriculture, and in part by an Arthur Boller Research Grant from the College of Agriculture and Life Science from Cornell University. Any opinions, findings, conclusions, or recommendations expressed in this publication are those of the authors and do not reflect the view of the U.S. Department of Agriculture. The first author was supported by the Conselho Nacional de Desenvolvimento Científico e Tecnológico-CNPq during the completion of his Ph.D. program at Cornell University.

\section{REFERENCES}

Aist JR, Gold RE, Bayles CJ, Morrison GH, Chandra S, Israel HW (1988) Evidence that molecular components of papillae may be involved in $\mathrm{ml}-\mathrm{o}$ resistance to barley powdery mildew. Physiological and Molecular Plant Pathology 33:17-32.

Baker CJ, Orlandi EW, Mock NM (1993) Harpin, an elicitor of the hypersensitive response in tobacco caused by Erwinia amylovora, elicits active oxygen production in suspension cells. Plant Physiology 102:1341-1344.

Benhamou N (1995) Elicitor-induced resistance in tomato plants against fungal pathogens: Ultrastructure and cytochemistry of the induced response. Scanning Microscopy 9:861-880.

Bussotti F, Gravano E, Grossoni P, Tani C (1998) Occurrence of tannins in leaves of beech trees (Fagus sylvatica) along an ecological gradient, detected by histochemical and ultrastrucural analyses. New Phytologist 138:469-479.

Capdeville G, Beer SV, Wilson CL, Aist JR (2002) Alternative disease control agents induced resistance to blue mold in harvested 'Red Delicious' apple fruit. Phytopathology 92:900-908.

Capdeville G, Beer SV, Watkins CB, Wilson CL, Aist JR (2003) Pre- and post-harvest harpin treatments of apples induce resistance to blue mold. Plant Disease 87:39-44.

Delaney TP (1997) Genetic dissection of acquired resistance to disease. Plant Physiology 113:5-12.

Dong H, Delaney TP, Bauer DW, Beer SV (1999) Harpin induces disease resistance in Arabidopsis through the systemic acquired resistance pathway mediated by salicylic acid and the NIMI gene. Plant Journal 20:207-215.

El Ghaouth A (1994) Manipulation of defense systems with elicitors to control postharvest diseases. In: Wilson CL, Wisniewski ME (Eds.) Biological control of postharvest diseases: Theory and practice. Boca Raton FL. CRC Press Inc. pp. 153-167

Esau K (1965) Plant anatomy. $2^{\text {nd }}$ ed. New York NY. John Wiley \& Sons Inc.

Fonseca JM, Kline WL, Wyenandt CA, Hoque M, Ajwa H (2005) Evaluation of a new harpin product on microbial quality and shelf life of minimally processed lettuce. http://cals.arizona.edu/pubs/ crops/az1382/az1382_1d.pdf (Access in sept. 10, 2007)

Ledbetter MC, Porter KR (1970) Introduction to the fine structure of plant cells. Berlin. Springer Verlag.

Lees GL, Wall KM, Beveridge TH, Suttill NH (1995) Localization 
of condensed tannin in apple fruit peel, pulp, and seeds. Canadian Journal of Botany 73:1897-1904.

Marshall MR, Smart MG, Aist JR, Israel HW (1984) Chlortetracycline and barley papilla formation: localization of calcium and alteration of response induced by Erysiphe graminis. Canadian Journal of Botany 63:876-880.

Mullin P, Wang JS, Qiu D, Wei ZM (1998) Disease control and growth enhancement effects of harpin on tobacco. Phytopathology (Suppl.)88:S65.

Peng JL, Dong HS, Dong HP, Delaney TP, Bonasera JM, Beer SV (2003) Harpin-elicited hypersensitive cell death and pathogen resistance require the NDR1 and EDS1 genes. Physiological and Molecular Plant Pathology 62:317-326.

Prusky D, Bazak M, Ben-Arie R (1985) Development, persistence, survival, and strategies for control of thiabendazole-resistant strains of Penicillium expansum on pome fruit. Phytopathology $75: 877-882$.

Rioux D, Biggs AR (1994) Cell wall changes in host and non-host systems: microscopic aspects. In: Petrini O, Ouellette GB (Eds.) Host wall alterations by parasitic fungi. Saint Paul MN. APS Press. pp. 31-44.

Snowdon AL (1990) Color atlas of post-harvest diseases and disorders of fruit and vegetables. Vol. 1. Boca Raton FL. CRC Press Inc.

Spiers AG, Brewster DT, Bus VG, Hopcroft DH (1998) Seasonal variation in susceptibility of xylem samples of Malus, Pyrus, Prunus, and Salix species to Chondrostereum purpureum in New Zealand. Mycological Research 102:881-890.

Terry LA, Joyce DC (2004) Elicitors of induced resistance in postharvest horticultural crops: a brief review. Postharvest Biology and Technology 32:1-13.

Wei ZM, Qiu D, Kropp MJ, Schading RL (1998) Harpin, an HR elicitor, activates both defense and growth systems in many commercially important crops. Phytopathology (Suppl.)88: S96.

Wilson CL, El-Gaouth A, Chalutz E, Droby S, Stevens C, Lu JY, Khan V, Arul J (1994) Potential of induced resistance to control postharvest diseases of fruit and vegetables. Plant Disease 78:837-844.

Yanga B, Shiping T, Jiec Z, Yonghong G (2005) Harpin induces local and systemic resistance against Trichothecium roseum in harvested Hami melons. Postharvest Biology and Technology $38: 183-187$.

Zitter TA, Beer SV (1998) Harpin for insect control. Phytopathology (Suppl.)88:S104-S105. 